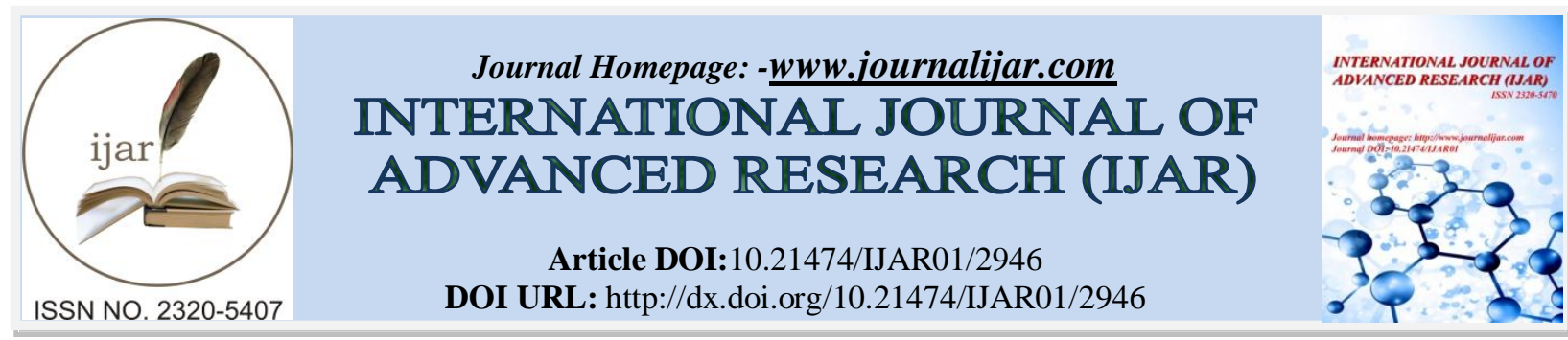

RESEARCH ARTICLE

\title{
CORRELATION OF CHILD'S AGGRESSIVE BEHAVIOR AND TELEVISION EXPOSURE: A CROSS SECTIONAL STUDY IN AL AHSA, KINGDOM OF SAUDI ARABIA
}
Muslem AlBesher, Mustafa Alqattan, Abdulhadia Imubarak, Maryam Al Besher, Haidar Al Habrati, Taleb Al Buali, Haidar Al Muhanna, Manea Almunjem and Abdulmonem Alismail.

\section{Manuscript Info}

Manuscript History

Received: 25 November 2016

Final Accepted: 27 December 2016

Published: January 2017

\begin{abstract}
Objective: establishing a clear and direct correlation between the aggressive behaviors of the children and the exposure to TV violent programs.

Method: 593 children represented the main sample of this research. $51,5 \%$ of the sample are males, whereas $48,5 \%$ are females. They had ages among 6 and 13 years old. They are residents in Al-Ahsa region (2016). The qui-square test was the main tool to check the influence of the TV watching by children and their aggressive actions.

Results: Almost all the respondents $(99,3 \%)$, reported watching TV, most of them reported watching TV 2 hours per day $(33,4 \%)$, while the most of the children $(43,7 \%)$ esteemed to watch TV a period that exceeds $4 \mathrm{hrs} /$ week. Data analysis prevailed that Children's the TV exposure was not related to children's behavior according to parents $(\mathrm{p}=0,379)$ and teachers $(\mathrm{p}=0,078)$.

Conclusion: Although this research detected a lowproportion of aggressive children, the aggressive behavior is still a recurrent broad global problem that should be reported and treated in early ages. This can happen through reducing the exposure to media as it the key reason for the growth of violence among children.
\end{abstract}

Copy Right, IJAR, 2016,. All rights reserved.

\section{Methodology:-}

The researcher depended on the descriptive analysis approach to estimate the socio-demographic factors and behavior characteristics under the influence of TV watching and computer use.

\section{Case study population:-}

It composed of children who are residents of Al-Ahsa region. They were withages among 6 and 13 years old. In this case study, the parents and the teachers have responded to 2 questionnaires (BPI questionnaires).

\section{Study tool:-}

The pre-formed and self-administered questionnaire was prepared and it requires information about:

1. Socio-demographic and lifestyle data such as: age, gender, residence, number of brothers and sisters, parent's education level, parent's monthly income, TV watching, average/day, average/week, Computer use, average computer/day, average computer/week.

Corresponding Author:-.

Address:- AlAhsa, Eastern Region, Kingdom of Saudi Arabia 
2. Behavior score by parents' assessment including 28 questions. A score of 1 was given to "always" and 2 to "sometimes" and 3 to "never". For each subject, the researcher calculated a maximum score of 84 . A scoring system was used with the purpose to measure the value of the respondents' aggressive behavior. The children behavior was categorized into 3 levels indicated by inadequate behavior (0-28), average behavior (29-56) and adequate behavior (57-84).

3. Behavior score by teachers' assessment including 25 questions. A score of 1 was given to "always" and 2 to "sometimes" and 3 to "never". For each subject, the researcher calculated a maximum score of 75. A scoring system was applied to measure the respondents' aggressive behavior. The children behavior was categorized into 3 levels indicated by inadequate behavior (0-25), average behavior (26-50) and adequate behavior (51-75).

\section{Statistical analysis:-}

(SPSS, version 20) was the program that was used to apply the descriptive analysis on the data using the Statistical Package for Social Sciences in the program.

The correlation of the participants' scores of the behaviors as a function of the exposure to TV was evaluated using:

1. The frequencies and the percentages.

2. The Chi-squared test which is famous for its accurate results.

The statistical significance for the data was accepted at value of $p<0.05$.

\section{Results:-}

Socio-demographic and lifestyle characteristics:-

The socio-demographic characteristics gave results that are listed in the next table (1)

Table 1:-Socio-demographic factors

\begin{tabular}{|c|c|c|c|}
\hline \multicolumn{2}{|c|}{ Data } & Frequency & Percent (\%) \\
\hline \multirow{4}{*}{ Residence } & Male & 305 & 51,5 \\
\cline { 2 - 4 } & Female & 287 & 48,5 \\
\cline { 2 - 4 } & Total & 592 & 100,0 \\
\hline & Falt & 295 & 50,2 \\
\hline & Small house & 144 & 24,5 \\
\hline & Villa & 141 & 24,0 \\
\hline & Other & 8 & 1,4 \\
\hline Income & 588 & 100,0 \\
\hline & Total & & 6,5 \\
\hline & & 38 & 42,6 \\
\hline & Poor & 248 & 40,9 \\
\hline & Enough & 238 & 10,0 \\
\hline & Average & 58 & 100,0 \\
\hline & High & 582 & 4,4 \\
\hline & Total & 26 & 10,9 \\
\hline & Father education & 64 & 29,5 \\
\hline & Illiterate & 173 & 17,7 \\
\hline & Primary & 104 & 37,5 \\
\hline & Intermediate & 220 & 100,0 \\
\hline & Secondary & 587 & 5,8 \\
\hline & Higher & & 15,7 \\
\hline & Total & 34 & 30,3 \\
\hline & Illiterate & 93 & 21,7 \\
\hline & Primary & 179 & 26,6 \\
\hline
\end{tabular}




\begin{tabular}{|l|l|c|c|}
\hline & Total & 591 & 100,0 \\
\hline & & & \\
\hline
\end{tabular}

Our study included 593 children from Al-Ahsa region aged between 6 and 13 years old with a meanage of $(7,90$ years). Overall, studied children had between 0 and 13 brothers (mean number: 2,53) and between 0 and 10 sisters (mean number: 2,33). By looking at table (1), related to the distribution of respondents according to demographic factors:

The survey included $(51,5 \%)$ of males and $(48,5 \%)$ of females.

Nearly the half of participants lived in Falt $(50,2 \%)$.

Most of the children's families had enough monthly income (42,6\%)and only $10 \%$ had a high monthly income.

The majority of the children had parents with education as follows:afather with high level of education (37,5\%) and a mother with an intermediate level of education $(30,3 \%)$.

The lifestyle characteristics are shown in tables below

Table:-Watching TV

\begin{tabular}{|c|c|c|c|}
\hline \multicolumn{2}{|c|}{ Data } & Frequency & Percent (\%) \\
\hline \multirow{4}{*}{ Watching TV } & & 99,3 \\
\cline { 2 - 4 } & Yes & 586 & 7 \\
\cline { 2 - 4 } & No & 4 & 100,0 \\
\hline Average/day & Total & 590 & 1,7 \\
\hline & & 10 & 31,5 \\
\hline & 1 hour & 184 & 33,4 \\
\hline & 2 hours & 195 & 20,7 \\
\hline & 3 hours & 121 & 10,8 \\
\hline & 4 hours & 63 & 1,9 \\
\hline & $>4$ hours & 11 & 100,0 \\
\hline Average/week & Total & 584 &, 2 \\
\hline & & & 5,9 \\
\hline & $<1$ hour & 1 & 13,1 \\
\hline & 1 hour & 34 & 12,2 \\
\hline & 2 hours & 75 & 24,9 \\
\hline & 3 hours & 70 & 43,7 \\
\hline & 4 hours & 143 & 100,0 \\
\hline
\end{tabular}

Approximately all of the children,(99,3\%), were reported to watch TV. While, 2hours per day TV viewing was reported by the third of participants $(33,4 \%)$,also $31,5 \%$ of respondents reported spending 1 hour daily watching television.

$43,7 \%$ of the children are esteemed to spend more than 4 hours weekly on TV watching.

Table :-Computer use

\begin{tabular}{|c|c|c|}
\hline Data & Frequency & Percent $(\%)$ \\
\hline \multicolumn{3}{|l|}{ Computer use } \\
\hline Yes & 501 & 85,5 \\
\hline No & 85 & 14,5 \\
\hline Total & 586 & 100,0 \\
\hline \multicolumn{3}{|l|}{ Average Computer/day } \\
\hline$<1$ hour & 17 & 3,5 \\
\hline
\end{tabular}




\begin{tabular}{|c|c|c|c|}
\hline & 1 hour & 269 & 54,9 \\
\hline & 2 hours & 125 & 25,5 \\
\hline & 3 hours & 47 & 9,6 \\
\hline & 4 hours & 21 & 4,3 \\
\hline & $>4$ hours & 7 & 1,4 \\
\hline & Other & 4 & 100,0 \\
\hline & Total & 490 &, 6 \\
\hline & & 17,0 \\
\hline & Average Computer/week & 84 & 17,8 \\
\hline & $<1$ hour & 88 & 17,8 \\
\hline & 1 hour & 88 & 24,4 \\
\hline & 2 hours & 121 & 22,4 \\
\hline & 3 hours & 111 & 100,0 \\
\hline & 4 hours & 495 & \\
\hline & $>4$ hours & & \\
\hline
\end{tabular}

High number and percentage, 501 and $85,5 \%$, of the little participants were report to using computer. Overall, almost the half of respondents $(54,9 \%)$ were allowed to use the computer 1 hour daily, while the quarter $(25,5 \%)$ used the computer 2 hours daily. Among the participants, approximately the quarter $(24,4 \%)$, were permitted to use the computer for 4 hours per week where $22,4 \%$ of children used computer for more than 4 hours weekly, and nearly $17 \%$ of the studied respondents used the computer 1 hour, 2 hours or 3 hours weekly $(17 \%, 17,8 \%, 17,8 \%$ respectively).

Behavior scores:-

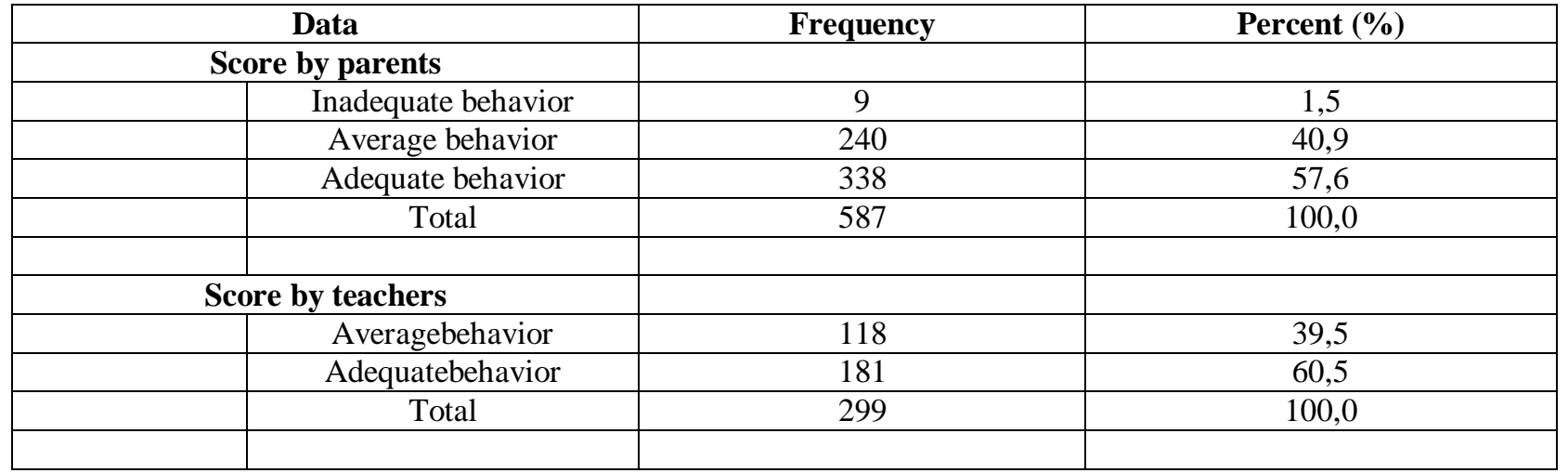

Referring to the responses of the parents, most of the children had an adequate behavior (57,6\%), where 40,9\% had average behavior, and only $1,5 \%$ had aggressive behavior.

Referring to the responses of the teachers, the majority of the investigated children $(60,5 \%)$ had an adequate behavior and approximately $39,5 \%$ of participants had average behavior.

The Correlation between the aggressive behavior of the children and the exposure to TV:-

Data analysis showed that Children's television exposure was not related to children's behavior according to parents $(\mathrm{p}=0,379)$ and teachers $(\mathrm{p}=0,078)$. Referring to the BPI by teachers $(\mathrm{p}=0,012)$, the study of relationship between the children's aggression and the television exposure showed a significant association between the aggressive actions against others and the daily-spent time in watching TV during childhood. On the other hand, referring to the BPI by parents $(p=0,212)$, the effect sizes for the relationship between television exposure and inadequate behavior were not statistically significant as it was close to zero. Furthermore, while a significant association was observed between weakly-TV exposure and child behavior according to parents, $(\mathrm{p}=0,000)$; the effect of weakly-TV exposure was not significant referring to the BPI by teachers, $(\mathrm{p}=0,104)$. 
Table:- Correlation between the aggressive behavior of children and the exposure to TV

Table:- Correlation between Childs aggressive behavior and TV exposure

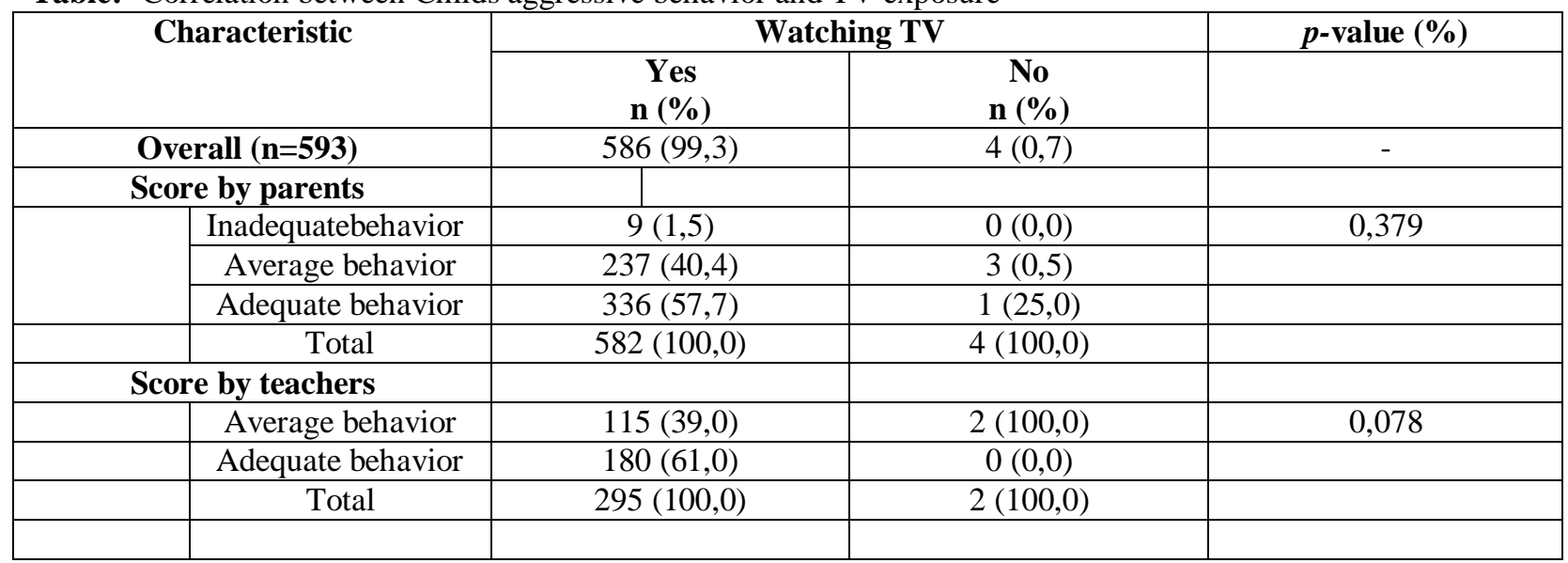

\begin{tabular}{|c|c|c|c|}
\hline \multicolumn{4}{|c|}{ Chi-Square Tests } \\
\hline Score by parents * Watching TV & Value & df & Asymp. Sig. (2-sided) \\
\hline Pearson Chi-Square & $1,942^{\mathrm{a}}$ & 2 &, 379 \\
\hline Likelihood Ratio & 1,977 & 2 &, 372 \\
\hline Linear-by-Linear Association & 1,392 & 1 &, 238 \\
\hline N of Valid Cases & 586 & & \\
\hline a. 3 cells of about (50,0\%) are expected to have count with less than 5. The minimum expected count is ,06. \\
\hline
\end{tabular}

\begin{tabular}{|c|c|c|c|c|c|}
\hline \multicolumn{6}{|c|}{ Chi-Square Tests } \\
\hline $\begin{array}{l}\text { Score by teachers * } \\
\text { Watching TV }\end{array}$ & Value & Df & $\begin{array}{l}\text { Asymp. Sig. } \\
\text { (2-sided) }\end{array}$ & $\begin{array}{l}\text { Exact Sig. (2- } \\
\text { sided) }\end{array}$ & $\begin{array}{l}\text { Exact Sig. (1- } \\
\text { sided) }\end{array}$ \\
\hline Pearson Chi-Square & $3,098^{\mathrm{a}}$ & 1 & ,078 & & \\
\hline Continuity Correction $^{b}$ & 1,069 & 1 & ,301 & & \\
\hline Likelihood Ratio & 3,747 & 1 &, 053 & & \\
\hline Fisher's Exact Test & & & &, 154 & ,154 \\
\hline $\begin{array}{l}\text { Linear-by-Linear } \\
\text { Association }\end{array}$ & 3,087 & 1 & ,079 & & \\
\hline $\mathrm{N}$ of Valid Cases & 297 & & & & \\
\hline a. 2 cells of about ( 5 & ve exp & hav & less than $5 . \mathrm{T}$ & imum expe & int is, 79 . \\
\hline & b. Th & anlys & $\mathrm{d}$ for a $2 \times 2 \mathrm{t}$ & & \\
\hline
\end{tabular}

Average/day * Score by parents.

\begin{tabular}{|c|c|c|c|c|c|c|}
\hline \multicolumn{7}{|c|}{ Crosstab } \\
\hline & & & \multicolumn{3}{|c|}{ Score by parents } & \multirow[t]{2}{*}{ Total } \\
\hline & & & $\begin{array}{c}\text { Inadequate } \\
\text { behavior }\end{array}$ & $\begin{array}{l}\text { Average } \\
\text { behavior }\end{array}$ & $\begin{array}{l}\text { Adequate } \\
\text { behavior }\end{array}$ & \\
\hline \multirow[t]{8}{*}{ Average/day } & \multirow{2}{*}{$\begin{array}{c}<1 \\
\text { hour }\end{array}$} & Count & 0 & 1 & 9 & 10 \\
\hline & & $\begin{array}{c}\% \text { within Score by } \\
\text { parents }\end{array}$ & $0,0 \%$ & $0,4 \%$ & $2,7 \%$ & $1,7 \%$ \\
\hline & \multirow[t]{2}{*}{1 hour } & Count & 2 & 82 & 96 & 180 \\
\hline & & $\begin{array}{c}\% \text { within Score by } \\
\text { parents }\end{array}$ & $28,6 \%$ & $34,5 \%$ & $28,7 \%$ & $31,0 \%$ \\
\hline & \multirow[t]{2}{*}{2 hours } & Count & 5 & 76 & 114 & 195 \\
\hline & & $\begin{array}{c}\% \text { within Score by } \\
\text { parents }\end{array}$ & $71,4 \%$ & $31,9 \%$ & $34,0 \%$ & $33,6 \%$ \\
\hline & \multirow[t]{2}{*}{3 hours } & Count & 0 & 53 & 68 & 121 \\
\hline & & $\%$ within Score by & $0,0 \%$ & $22,3 \%$ & $20,3 \%$ & $20,9 \%$ \\
\hline
\end{tabular}




\begin{tabular}{|c|c|c|c|c|c|c|}
\hline & & parents & & & & \\
\hline & \multirow[t]{2}{*}{4 hours } & Count & 0 & 23 & 40 & 63 \\
\hline & & $\begin{array}{c}\% \text { within Score by } \\
\text { parents }\end{array}$ & $0,0 \%$ & $9,7 \%$ & $11,9 \%$ & $10,9 \%$ \\
\hline & \multirow{2}{*}{$\begin{array}{c}>4 \\
\text { hours }\end{array}$} & Count & 0 & 3 & 8 & 11 \\
\hline & & $\begin{array}{c}\% \text { within Score by } \\
\text { parents }\end{array}$ & $0,0 \%$ & $1,3 \%$ & $2,4 \%$ & $1,9 \%$ \\
\hline \multirow{2}{*}{\multicolumn{2}{|c|}{ Total }} & Count & 7 & 238 & 335 & 580 \\
\hline & & $\begin{array}{c}\% \text { within Score by } \\
\text { parents }\end{array}$ & $100,0 \%$ & $100,0 \%$ & $100,0 \%$ & $100,0 \%$ \\
\hline
\end{tabular}

\begin{tabular}{|c|c|c|c|}
\hline \multicolumn{4}{|c|}{ Chi-Square Tests } \\
\hline & Value & df & Asymp. Sig. (2-sided) \\
\hline Pearson Chi-Square & $13,220^{\mathrm{a}}$ & 10 &, 212 \\
\hline Likelihood Ratio & 15,754 & 10 &, 107 \\
\hline Linear-by-Linear Association & 1,183 & 1 &, 277 \\
\hline N of Valid Cases & 580 & & \\
\hline a. 8 cells of about (44,4\%) are expected to have count less than 5. The minimum expected count is ,12. \\
\hline
\end{tabular}

Average/day * Score by teachers

\begin{tabular}{|c|c|c|c|c|c|}
\hline \multicolumn{6}{|c|}{ Crosstab } \\
\hline & & & \multicolumn{2}{|c|}{ Score by teachers } & \multirow[t]{2}{*}{ Total } \\
\hline & & & $\begin{array}{l}\text { Average } \\
\text { behavior }\end{array}$ & $\begin{array}{l}\text { Adequate } \\
\text { behavior }\end{array}$ & \\
\hline \multirow[t]{12}{*}{ Average/day } & \multirow[t]{2}{*}{$<1$ hour } & Count & 0 & 3 & 3 \\
\hline & & $\%$ within Score by teachers & $0,0 \%$ & $1,7 \%$ & $1,0 \%$ \\
\hline & \multirow[t]{2}{*}{1 hour } & Count & 32 & 59 & 91 \\
\hline & & $\%$ within Score by teachers & $27,8 \%$ & $33,1 \%$ & $31,1 \%$ \\
\hline & \multirow[t]{2}{*}{2 hours } & Count & 44 & 49 & 93 \\
\hline & & $\%$ within Score by teachers & $38,3 \%$ & $27,5 \%$ & $31,7 \%$ \\
\hline & \multirow[t]{2}{*}{3 hours } & Count & 32 & 35 & 67 \\
\hline & & $\%$ within Score by teachers & $27,8 \%$ & $19,7 \%$ & $22,9 \%$ \\
\hline & \multirow[t]{2}{*}{4 hours } & Count & 6 & 27 & 33 \\
\hline & & $\%$ within Score by teachers & $5,2 \%$ & $15,2 \%$ & $11,3 \%$ \\
\hline & \multirow[t]{2}{*}{$>4$ hours } & Count & 1 & 5 & 6 \\
\hline & & $\%$ within Score by teachers & $0,9 \%$ & $2,8 \%$ & $2,0 \%$ \\
\hline \multirow{2}{*}{\multicolumn{2}{|c|}{ Total }} & Count & 115 & 178 & 293 \\
\hline & & $\%$ within Score by teachers & $100,0 \%$ & $100,0 \%$ & $100,0 \%$ \\
\hline
\end{tabular}

\begin{tabular}{|c|c|c|c|}
\hline \multicolumn{4}{|c|}{ Chi-Square Tests } \\
\hline & Value & Df & Asymp. Sig. (2-sided) \\
\hline Pearson Chi-Square & $14,572^{\mathrm{a}}$ & 5 &, 012 \\
\hline Likelihood Ratio & 16,408 & 5 &, 006 \\
\hline Linear-by-Linear Association &, 463 & 1 &, 496 \\
\hline N of Valid Cases & 293 & & \\
\hline a. 4 cells of approximately (33,3\%) are expected to have count less than 5. The minimum expected count is 1,18. \\
\hline
\end{tabular}


Average/week * Score by parents.

\begin{tabular}{|c|c|c|c|c|c|c|}
\hline \multicolumn{7}{|c|}{ Crosstab } \\
\hline & & & \multicolumn{3}{|c|}{ Score by parents } & \multirow[t]{2}{*}{ Total } \\
\hline & & & $\begin{array}{c}\text { Inadequate } \\
\text { behavior }\end{array}$ & $\begin{array}{l}\text { Average } \\
\text { behavior }\end{array}$ & $\begin{array}{l}\text { Adequate } \\
\text { behavior }\end{array}$ & \\
\hline \multirow[t]{12}{*}{ Average/week } & \multirow{2}{*}{$\begin{array}{c}<1 \\
\text { hour }\end{array}$} & Count & 0 & 1 & 0 & 1 \\
\hline & & $\begin{array}{c}\text { \% within Score by } \\
\text { parents }\end{array}$ & $0,0 \%$ & $0,4 \%$ & $0,0 \%$ & $0,2 \%$ \\
\hline & \multirow[t]{2}{*}{1 hour } & Count & 2 & 10 & 21 & 33 \\
\hline & & $\begin{array}{c}\% \text { within Score by } \\
\text { parents }\end{array}$ & $28,6 \%$ & $4,3 \%$ & $6,3 \%$ & $5,8 \%$ \\
\hline & \multirow[t]{2}{*}{2 hours } & Count & 0 & 47 & 28 & 75 \\
\hline & & $\begin{array}{c}\text { \% within Score by } \\
\text { parents }\end{array}$ & $0,0 \%$ & $20,1 \%$ & $8,5 \%$ & $13,1 \%$ \\
\hline & \multirow[t]{2}{*}{3 hours } & Count & 0 & 38 & 32 & 70 \\
\hline & & $\begin{array}{c}\% \text { within Score by } \\
\text { parents }\end{array}$ & $0,0 \%$ & $16,2 \%$ & $9,7 \%$ & $12,2 \%$ \\
\hline & \multirow[t]{2}{*}{4 hours } & Count & 2 & 49 & 91 & 142 \\
\hline & & $\begin{array}{c}\text { \% within Score by } \\
\text { parents }\end{array}$ & $28,6 \%$ & $20,9 \%$ & $27,5 \%$ & $24,8 \%$ \\
\hline & \multirow{2}{*}{$\begin{array}{c}>4 \\
\text { hours }\end{array}$} & Count & 3 & 89 & 159 & 251 \\
\hline & & $\begin{array}{c}\% \text { within Score by } \\
\text { parents }\end{array}$ & $42,9 \%$ & $38,0 \%$ & $48,0 \%$ & $43,9 \%$ \\
\hline \multirow{2}{*}{\multicolumn{2}{|c|}{ Total }} & Count & 7 & 234 & 331 & 572 \\
\hline & & $\begin{array}{c}\% \text { within Score by } \\
\text { parents }\end{array}$ & $100,0 \%$ & $100,0 \%$ & $100,0 \%$ & $100,0 \%$ \\
\hline
\end{tabular}

\begin{tabular}{|c|c|c|c|}
\hline \multicolumn{4}{|c|}{ Chi-Square Tests } \\
\hline & Value & df & Asymp. Sig. (2-sided) \\
\hline Pearson Chi-Square & $35,155^{\text {a }}$ & 10 &, 000 \\
\hline Likelihood Ratio & 33,768 & 10 &, 000 \\
\hline Linear-by-Linear Association & 10,716 & 1 &, 001 \\
\hline N of Valid Cases & 572 & & \\
\hline a. 8 cells of about (44,4\%) are expected to have count less than 5. The minimum expected count is ,01. \\
\hline
\end{tabular}

Average/week * Score by teachers.

\begin{tabular}{|c|c|c|c|c|c|}
\hline \multicolumn{6}{|c|}{ Crosstab } \\
\hline & & & \multicolumn{2}{|c|}{ Score by teachers } & \multirow[t]{2}{*}{ Total } \\
\hline & & & $\begin{array}{l}\text { Average } \\
\text { behavior }\end{array}$ & $\begin{array}{l}\text { Adequate } \\
\text { behavior }\end{array}$ & \\
\hline \multirow[t]{12}{*}{ Average/week } & \multirow[t]{2}{*}{0} & Count & 0 & 1 & 1 \\
\hline & & $\%$ within Score by teachers & $0,0 \%$ & $0,6 \%$ & $0,3 \%$ \\
\hline & \multirow[t]{2}{*}{1 hour } & Count & 6 & 3 & 9 \\
\hline & & $\%$ within Score by teachers & $5,3 \%$ & $1,7 \%$ & $3,1 \%$ \\
\hline & \multirow[t]{2}{*}{2 hours } & Count & 8 & 26 & 34 \\
\hline & & $\%$ within Score by teachers & $7,1 \%$ & $15,0 \%$ & $11,9 \%$ \\
\hline & \multirow[t]{2}{*}{3 hours } & Count & 17 & 16 & 33 \\
\hline & & $\%$ within Score by teachers & $15,0 \%$ & $9,2 \%$ & $11,5 \%$ \\
\hline & \multirow[t]{2}{*}{4 hours } & Count & 25 & 41 & 66 \\
\hline & & $\%$ within Score by teachers & $22,1 \%$ & $23,7 \%$ & $23,1 \%$ \\
\hline & \multirow[t]{2}{*}{$>4$ hours } & Count & 57 & 86 & 143 \\
\hline & & $\%$ within Score by teachers & $50,4 \%$ & $49,7 \%$ & $50,0 \%$ \\
\hline \multicolumn{2}{|c|}{ Total } & Count & 113 & 173 & 286 \\
\hline
\end{tabular}




\begin{tabular}{|c|c|c|c|c|}
\hline & $\%$ within Score by teachers & $100,0 \%$ & $100,0 \%$ & $100,0 \%$ \\
\hline \multicolumn{5}{|c|}{ Chi-Square Tests } \\
\hline & Value & df & Asymp & 2 -sided) \\
\hline Pearson Chi-Square & 9,134 & 5 & & ,104 \\
\hline Likelihood Ratio & 9,628 & 5 & & ,086 \\
\hline Linear-by-Linear Association &, 028 & 1 & & ,867 \\
\hline $\mathrm{N}$ of Valid Cases & 286 & & & \\
\hline
\end{tabular}

\section{Recommendations:-}

Huesmann, L. R. et al. mentioned that children as increasingly becoming heavy media consumers (1), they also noted the violent content of much of the media directed at children and their harmful influence on the advancement of the outcomes of the behaviors of the children. This study suggests that the ACT program can detect the influence of media violence on the advancement of the young children, and it can teach parents some strategies that can help them decreasing the watching of violence TV programs by their children. Further, the researchers recommended the restriction as much as possible of violent TV programs by parents for young children and preteens, and stressed on the importance of the strict control on the media content before allowing their child to view TV programs even those that seemed to be safe.

In addition, the American Academy of Pediatrics suggested dropping the total time that children spend watching TV to just 1 to $2 \mathrm{hrs} /$ day high quality entertainment programs (2) and this suggestion was also adopted by Robertson LA et al. who wanted to study "check if the excessive watching of the television during the childhood and the adolescence is related to the increased antisocial behavior in the early adulthood" (3), in fact researchers have found that each extra hour of watching the TV can increase the tendency to the odds for antisocial outcomes.

Behavior aggression is multi-factorie, it can also be present as a part of other neuro-psychic disorders and psychiatric syndromes (autism, Tourette...), or related to direct or indirect exposure to violence (4), in all cases children should be supported at many levels: socially by parents and close entourage, and at larger scale by the teachers or even medical stuff experts. Actually, several aggressively control activities can be set ${ }^{1}$ to help children to solve their violent behavior issues. Ruble and Seidman (Ruble \&Seidman, 1996, cited in National Crime Prevention 1999: 52) reported the need for preventive programs targeting the child and his parents. Hence sincere work should be exerted to at the level of the parents / children relationship. Additionally as verbal skills had found to be inversely correlated with the impulsivity and the crime behavior (Moffitt, 1993; Lynam, Moffit\&Stouhamer-Loeber, 1993; Moffitt\& Silva, 1988), butter communication skills by early language intervention and development makes easy for the child to socialise (Keenan \& Shaw, 1997) and feel being understood.

High quality care of children is essential as it seems that the behavior of the children has a direct relationship with the quality of this care. In their study Vandel and Wolfe (Vandell\& Wolfe, 2000) have found that the more quality of care was high, the fewer reports of behavior problems were.

Parents and educators could also play a primordial role helping children to develop social kills, by being patients and spending more time directly teaching them skills.

\section{Conclusion:-}

According to this research, most of the children that were included in this study showed an adequate behavior.On the other hand, although both parents and teachers detected low proportions of aggressive children, effective efforts and strategies for reducing children's exposure to media should be followed.This is because many studies stated the negative effect of the exposure to TV on the health and the behavior of the children. This can surely avoid the society the risk of the development of the aggressive and violent actions and behaviors in adulthood. 


\section{Acknowledgement :-}

We would like to thank Dr. Fatima AlGhazal, Emad AlEthan, Eman AlKishi, and Ammar AlKhars for their role in data collection.

\section{References:-}

1. Huesmann LR, Moise-Titus J, Podolski C-L, Eron LD. Longitudinal relations between children's exposure to TV violence and their aggressive and violent behavior in young adulthood: 1977-1992. Developmental psychology. 2003;39(2):201.

2. American Academy of Pediatrics: Children, adolescents, and television. Pediatrics. 2001 Feb;107(2):423-6. PubMed PMID: 11158483. Epub 2001/02/07. eng.

3. Robertson LA, McAnally HM, Hancox RJ. Childhood and Adolescent Television Viewing and Antisocial Behavior in Early Adulthood. Pediatrics. 2013 10/26/accepted;131(3):439-46. PubMed PMID: PMC3581845.

4. Reebye P. Aggression During Early Years - Infancy and Preschool. The Canadian child and adolescent psychiatry review. 2005 Feb;14(1):16-20. PubMed PMID: 19030496. 